\title{
In vitro anticandidal activity and gas chromatography-mass spectrometry (GC-MS) screening of Vitex agnus-castus leaf extracts
}

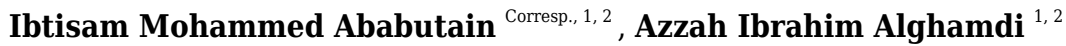 \\ ${ }^{1}$ Basic \& Applied Scientific Research Center (BASRC), Imam Abdulrahman Bin Faisal University, Dammam, Saudi Arabia \\ 2 Department of Biology, College of Science, Imam Abdulrahman Bin Faisal University, Dammam, Saudi Arabia \\ Corresponding Author: Ibtisam Mohammed Ababutain \\ Email address: iababutain@iau.edu.sa
}

Background Candida infections are becoming more drug resistant; it is necessary to search for alternative medications to treat them. Therefore, the present study estimates the anticandidal activity of Vitex agnus-castus (VA-C) leaf extracts. Methods We used the agar well diffusion method to assess the anticandidal activity of three different VA-C leaf extracts (ethanol, methanol, and water) against three Candida species (Candida tropicalis, Candida albicans, and Candida ciferrii). The minimum inhibitory concentration (MIC) was estimated using the two-fold dilution method and the minimum fungicidal concentration (MFC) was determined using the classic pour plate technique. The MFC/MIC ratio was calculated to estimate the microbicidal or microbiostatic activity. A gas chromatography mass spectrometer was used to screen the phytochemicals of the VA-C leaf extracts (ethanol, methanol, and water). Results All VA-C extracts ethanol, methanol, and water were significantly inhibited the growth of the test Candida species and the inhibition activity depended on the solvent used and the Candida species. The results showed that $C$. tropicalis was the most highly inhibited by all extracts followed by $C$. albicans and $C$. ciferrii. The MIC values were $12.5 \mu \mathrm{g} / \mathrm{ml}$ to $25 \mu \mathrm{g} / \mathrm{ml}$, and MFC values were $25 \mu \mathrm{g} / \mathrm{ml}$ to 100 $\mu \mathrm{g} / \mathrm{ml}$. The ratios of MFC/MIC were two-fold to four-fold which was considered candidacidal activity. Ninety-five phytochemical compounds were identified by the GC-MS assay for the VA-C leaf extracts. The total number of compounds per extract differed. Methanol had 43 compounds, ethanol had 47 compounds, and water had 52 compounds. The highest compound concentrations were: 4,5-Dichloro-1,3-dioxolan-2-one in ethanol and methanol, 1H-Indene, 2,3-dihydro-1,1,2,3,3-pentamethyl in ethanol, Isobutyl 4-hydroxybenzoate in methanol, and Benzoic acid and 4-hydroxy- in water. These phytochemical compounds belong to different bioactive chemical group such as polyphenols, fatty acids, terpenes, terpenoids, steroids, aldehydes, alcohols, and esters, and most of which have anticandidal activity. Conclusions VA-C leaf extracts may be useful alternatives to anticandidal drugs, 
based on their effectiveness against all test Candida species at low concentrations. However, appropriate toxicology screening should be conducted before use. 
1 In vitro anticandidal activity and gas chromatography-mass spectrometry (GC-MS) screening of

2 Vitex agnus-castus leaf extracts

3

4 Ibtisam Mohammed Ababutain ${ }^{1,2, *}$, Azzah Ibrahim Alghamdi ${ }^{1,2}$

5

$6{ }^{1}$ Department of Biology, College of Science, Imam Abdulrahman Bin Faisal University, P.O. Box 7 1982, 31441, Dammam, Saudi Arabia.

8

9 2Basic \& Applied Scientific Research Center (BASRC), Imam Abdulrahman Bin Faisal 10 University, P.O. Box 1982, 31441, Dammam, Saudi Arabia.

*Corresponding author: Ibtisam Mohammed Ababutain (iababutain@iau.edu.sa; 13 Dr.King2007@,hotmail.com);

14

15

17

\section{ABSTRACT}

Background

Candida Infections are becoming more drug resistant; it is necessary to search for alternative medications to treat them. Therefore, the present study estimates the anticandidal activity of Vitex agnus-castus (VA-C) leaf extracts.

\section{Methods}

We used the agar well diffusion method to assess the anticandidal activity of three different VA-C leaf extracts (ethanol, methanol, and water) against three Candida species (Candida tropicalis, Candida albicans, and Candida ciferrii). The minimum inhibitory concentration (MIC) was estimated using the two-fold dilution method and the minimum fungicidal concentration (MFC) was determined using the classic pour plate technique. The MFC/MIC ratio was calculated to estimate the microbicidal or microbiostatic activity. A gas chromatography mass spectrometer was used to screen the phytochemicals of the VA-C leaf extracts (ethanol, methanol, and water).

\section{Results}


All VA-C extracts ethanol, methanol, and water were significantly inhibited the growth of the test Candida species and the inhibition activity depended on the solvent used and the Candida species. The results showed that $C$. tropicalis was the most highly inhibited by all extracts followed by $C$. albicans and $C$. ciferrii. The MIC values were $12.5 \mu \mathrm{g} / \mathrm{ml}$ to $25 \mu \mathrm{g} / \mathrm{ml}$, and MFC values were $25 \mu \mathrm{g} / \mathrm{ml}$ to $100 \mu \mathrm{g} / \mathrm{ml}$. The ratios of MFC/MIC were two-fold to four-fold which was considered candidacidal activity. Ninety-five phytochemical compounds were identified by the GC-MS assay for the VA-C leaf extracts. The total number of compounds per extract differed. Methanol had 43 compounds, ethanol had 47 compounds, and water had 52 compounds. The highest compound concentrations were: 4,5-Dichloro-1,3-dioxolan-2-one in ethanol and methanol, 1H-Indene, 2,3-dihydro-1,1,2,3,3-pentamethyl in ethanol, Isobutyl 4-hydroxybenzoate in methanol, and Benzoic acid and 4-hydroxy- in water. These phytochemical compounds belong to different bioactive chemical group such as polyphenols, fatty acids, terpenes, terpenoids, steroids, aldehydes, alcohols, and esters, and most of which have anticandidal activity.

\section{Conclusions}

VA-C leaf extracts may be useful alternatives to anticandidal drugs, based on their effectiveness against all test Candida species at low concentrations. However, appropriate toxicology screening should be conducted before use.

\section{Introduction}

The number of severe Candida infections is on the rise, which is concerning due to their virulence, ability to survive in extreme environments, and resistance to antifungal agents (Paramythiotou et al., 2014). Candida species can cause a wide variety of infections ranging from mild to severe, such as candidemia which has a mortality rate up to $38 \%$ in immunosuppressed patients (i.e. organ transplantation patients, patients under chemotherapy, HIV- infected, and diabetic) (Koehler et al., 2019; de Oliveira Santos et al., 2018). The rate of fungal infections, including candidiasis, can reach $20 \%$ in the intensive care unit and antifungal medications including azoles, echinocandins, fluoropyrimidines, and polyenes are typically used to treat these infections. However, determining the appropriate dose for treatment is challenging when considering their side effects (Chatelon et al., 2019). Candidiasis is one of the most common fungal diseases in the world and includes cutaneous candidiasis, mucosal candidiasis, onychomycosis, and systemic candidiasis. Healthy individuals are also susceptible to candidiasis (de Oliveira Santos et al., 2018). Genus Candida is deuteromycetes fungi and belongs to the Cryptococcaceae family, with up to 200 species. There are thirty species most commonly isolated in human infections including Candida albicans, Candida tropicalis, Candida dubliniensis, Candida parapsilosis, Candida glabrata, Candida lusitaniae, Candida kefyr, and Candida krusei (Rodrigues et.al., 2019; Kim et al., 2016; Brandt and Lockhart, 2012; Miceli et al., 2011). 
Antifungals have a broad range of applications but it is difficult to determine the ideal treatment regime because their use can be limited and is often accompanied by side effects. The indiscriminate use of antibiotics has led to an increased resistance to these types of medications (de Oliveira Santos et al., 2018). Accordingly, researchers are exploring therapeutic alternatives, such as the use of plant essential oils or extracts. These have been proven beneficial in the treatment of several diseases due to their phytochemical components that have physiological and therapeutic effects on humans, limited toxicity, and low therapeutic costs (Abdulrasheed et al., 2019; Sardi et al., 2013). The World Health Organization reports indicate that up to $25 \%$ of modern medicines used in the United States of America originate from plants. In Africa and Asia, 80\% of the population still uses medicinal herbs in their primary health care centers (WHO, 2002). Moreover, there is documented evidence for the antimicrobial potential of more than 1340 plants (Yilar et al., 2016). Vitex is one of the largest of the 250 genera in the family Verbenaceae found worldwide (Ganapaty and Vidyadhar, 2005). The therapeutic applications of Vitex agnus-castus (VA-C) and its safety as a medicinal plant are well stated (Niroumand et al., 2018; Neves and da Camara, 2016; Rani and Sharma, 2013). Previous studies have emphasized the antibacterial activity of the essential oils extracted from the seeds and fruit of VA-C (Eryigit et al., 2015; Dervishi-Shengjergji et al., 2014; Ghannadi et al., 2012). Other studies have investigated the antimicrobial activity of essential oils extracted from the leaves of VA-C (Katiraee et al., 2015; Ulukanli et al., 2015). A few studies have demonstrated the antifungal activity of the seed oil (Asdadi et al., 2014). The antifungal potential of VA-C leaves essential oils against plant pathogens (Yilar et al., 2016). The antibacterial activity of the leaf extract of VA-C has been identified in a few studies (Ababutain and Alghamdi, 2018; Kalhoro et al., 2014; Arokiyaraj et al., 2009) as well as the antimicrobial activity of VA-C leaf extract (Kalhoro et al., 2014; Maltaş et al., 2010). These studies used only a few bacteria and one Candida species (Candida albicans). Keikha et al. (2018) evaluated the antifungal activity of ethanolic and aqueous lead extracts on $C$. albicans strains and they found that the ethanol extract was more effective than the aqueous extract against $C$. albicans strains. However, the effect of VA-C leaf extracts of against human Candida species has not been wellstudied.

Therefore, this study aims to investigate the anticandidal activity and efficiency of VA-C leaf extracts (water, methanol and ethanol) against the three most frequently isolated Candida species (Candida albicans, Candida tropicalis and Candida ciferrii). We determined the phytochemicals of these extracts using Gas Chromatography-Mass Spectrometry (GC-MS).

\section{Materials \& Methods}

Plant material

Vitex agnus-castus VA-C leaves were collected from a private garden in Dammam City, Saudi Arabia belonging to Ibtisam Mohammed Ababutain. The plant was identified according to Brickell and Zuk (1997).

Preparation of plant extracts 
111

112

113

114

115

116

117

118

119

120

121

122

123

124

125

126

127

128

129

130

131

132

133

134

135

136

137

138

139

140

141

142
VA-C leaves were washed with tap water and left to dry for two days at room temperature in a well-ventilated room using a fan to speed up the drying process, then ground to a fine powder. Maceration method described by Pandey and Tripathi (2014) was used with little modification, in which $60 \mathrm{~g}$ of the leaf powder was transferred to three Erlenmeyer flasks containing $300 \mathrm{~mL}$ of the three different solvents: distilled water, methanol $(80 \%)$, and ethanol $(80 \%)$ to a final concentration of $20 \% \mathrm{~g} / \mathrm{mL}$. The leaf mixtures were shaken for 72 hours at $300 \mathrm{rpm} / \mathrm{min} / 20^{\circ} \mathrm{C}$ to extract the active compounds. We used the method previously described in Ababutain (2019) to extract the active compounds as follows: the leaf mixtures were filtered twice, first using Whatman No. 1 filter paper and then using bacterial filters. The filtrates were concentrated in an oven at $80^{\circ} \mathrm{C}$. The residues were re-suspended in dimethyl sulfoxide (DMSO) to a final concentration of $20 \%$. All flasks were kept at $4^{\circ} \mathrm{C}$ for further use.

Agar well-diffusion method

Three different prepared VA-C leaf extracts with a $20 \%(\mathrm{mg} / \mathrm{ml})$ concentration were screened for their anticandidal activity using the agar well-diffusion method (NCCLS, 1993) against three unicellular fungi. Candida tropicalis and Candida albicans were provided by King Fahd Hospital, Al Khobar, Kingdom of Saudi Arabia. Candida ciferrii was obtained from the Biology Department, College of Science, Imam Abdulrahman Bin Faisal University.

Inoculums of the Candida species were prepared from new cultures in potato dextrose broth (PDB). A Biomerieux DensiCHEK plus meter device was used to adjust the cell suspension turbidity at 1-2 x $10^{6} \mathrm{CFU} / \mathrm{ml}$, which represents $0.5 \mathrm{McF}$ arland standards. Each Petri dish was inoculated individually with $0.5 \mathrm{ml}$ of the previous suspension. Melted potato dextrose agar (PDA) was poured over the inoculums, and the plates were rotated to ensure even distribution of the inoculums then left to harden at room temperate for $5 \mathrm{~min}$. Five wells were made on the inoculated PDA using a $6 \mathrm{~mm}$ sterile cork-borer. Each well was filled with $100 \mu \mathrm{L}$ of the plant extracts. Positive and negative controls were included; nystatin $(10 \mathrm{mcg})$ was used as the positive control and DMSO was used as the negative control. The plates were incubated at $37^{\circ} \mathrm{C}$ for 24 hours. The anticandidal activity of the plant extracts was estimated in millimeters $(\mathrm{mm})$ using a ruler and measuring the free growth zones around the wells. The experiments were performed in three replicates to ensure the reliability of the results.

Determination of minimum inhibitory concentration (MIC) 
143

144

145

146

147

148

149

150

151

152

153

154

155

156

157

158

159

160

161

162

163

164

165

166

167

168

169

170

171

172

173

174

175

176

177

178

179

180

181

The minimum inhibitory concentration (MIC) of VA-C leaf extracts was estimated using the two-fold dilution method (Omura et al., 1993) as well as the method previously described in Ababutain (2019). Briefly, the plant extracts were diluted with PDB media using 96-well microtiter plates in wells 1 to 10 . Standard Candida inoculums at a concentration of $1-2 \times 10^{6} \mathrm{CFU} / \mathrm{mL}$ were transferred to the wells to make a final concentration of $50 \%$. We used growth media with the Candida inoculum in well 11 and growth media with plant extracts in well 12, as positive and negative controls, respectively. The turbidity was examined by the naked eye after an overnight incubation period at $37^{\circ} \mathrm{C}$ and the lowest concentration of plant extract showing no Candida species growth was recorded as MICs. All experiments were performed in three replicates.

\section{Determination of minimum fungicidal concentration (MFC)}

The classic pour plate technique was used to determine the MFC (NCCLS, 1997). Concentrations that showed no Candida species growth from previous MIC experiments were transferred to Petri dishes, then $15 \mathrm{~mL}$ of melted PDA was poured over it and gently rotated and left to solidify. Inoculated Petri dishes were incubated at $37^{\circ} \mathrm{C}$ for 48 hours. The lowest concentration that showed no visible Candida species colonies were recorded as MFC (Ababutain, 2019). All experiments were performed in three replicates.

\section{Determination of anticandidal efficiency}

The anticandidal efficiency of VA-C leaf extracts (ethanol, methanol and water) was determined by calculating the ratio of MFC/MIC according to Levison and Levison (2009).

Gas chromatography-mass spectrometry (GC-MS)

We analyzed the bioactive compounds of all three VA-C leaf extracts (ethanol, methanol and water) with a gas chromatography-mass spectrometer (Shimadzu-Japan) model QP2010 SE, with a 5 Sil MS 5\% diphenyl/ 95\% dimethyl polysiloxane capillary column $(0.25-\mu \mathrm{m} \mathrm{df}, 30 \mathrm{~meter}$, $0.25 \mathrm{mmID}$ ) using the method previously described in Ababutain (2019). One microliter from each diluted plant extract (100/1400, V/V in DMSO) was injected individually in the split mode with a split ratio of $1: 10$. We used the electron impact ionization system at $70 \mathrm{eV}$ ionization energy to determine GC-MS exposure or detection. Pure helium (99.999\%) was used as a carrier gas, at a constant column flow $0.7 \mathrm{ml} / \mathrm{min}$ and total flow of $10.4 \mathrm{ml} / \mathrm{min}$. The flow control mode had a linear velocity of $29.6 \mathrm{~cm} / \mathrm{sec}$. The injector temperature was set at $250^{\circ} \mathrm{C}$ and the ion-source temperature was set at $250^{\circ} \mathrm{C}$. The column temperature was programmed at $50^{\circ} \mathrm{C}$ to $300^{\circ} \mathrm{C}$, with a hold time of $3 \mathrm{~min}$, and a total run time of $29 \mathrm{~min}$. The chemical compounds were identified using the National Institute of Standards and Technology (NIST 08) library match and the quantitative data were generated automatically as a percentage (Adams, 2007).

Statistical analysis

Peer] reviewing PDF | (2020:07:51312:1:1:NEW 6 Nov 2020) 
182

183

184

185

186

187

188

189

190

191

192

193

194

195

196

197

198

199

200

201

202

203

204

205

206

207

208

209

210

211

212

213

214

The anticandidal activity of the VA-C leaf extract between the solvents and the Candida species was conducted using one-way Anova test. A $P$-value of $<0.01$ was considered statistically significant. Statistical data were analyzed using Statistical Packages for Software Sciences (SPSS, 2013) version 21 Armonk, New York, IBM Corporation.

\section{Results}

Anticandidal activity of VA-C leaf extracts

The VA-C extracts were shown to inhibit the growth of all tested Candida species and the inhibition activity depended on the solvent type and Candida species. The results showed that $C$. tropicalis was the most inhibited by all the extracts followed by $C$. albicans and $C$. ciferrii (all $\mathrm{P}=0.01$ ). The effects of the ethanol extract against $C$. tropicalis, $C$. albicans and $C$. ciferrii were significantly higher compared to water and methanol extracts at $\mathrm{P}=0.01, \mathrm{P}=0.037$ and $\mathrm{P}=0.047$, respectively (Table 1).

MIC results were between $12.5 \mu \mathrm{g} / \mathrm{ml}$ to $25 \mu \mathrm{g} / \mathrm{ml}$ and all extracts showed similar activity against all Candida species at MIC $25 \mu \mathrm{g} / \mathrm{ml}$, except $C$. tropicalis which was the most sensitive to the ethanol extract at MIC12.5 $\mu \mathrm{g} / \mathrm{ml}$. The MFC results were between $25 \mu \mathrm{g} / \mathrm{ml}$ to $100 \mu \mathrm{g} / \mathrm{ml}$. Most extracts showed similar MFC values against all Candida species at MFC $50 \mu \mathrm{g} / \mathrm{ml}$ except $C$. tropicalis. The MFC ethanol extract at $25 \mu \mathrm{g} / \mathrm{ml}$ had the highest anticandidal activity against $C$. tropicalis and the MFC methanol extract at $100 \mu \mathrm{g} / \mathrm{ml}$ was considered to be the lowest anticandidal activity against $C$. albicans. The results revealed that both MIC and MFC values for all three solvents were narrow where the differences between values were one to two concentrations only. The MFC/MIC ratio in all the three extracts were only two-fold to four-fold, which means that VA-C leaf extracts are potentially candidacidal (Table 2).

Gas chromatography -mass spectrometry (GC-MS) analysis

Our results revealed that VA-C leaf extracts are rich in phytochemical components of different concentrations. 95 chemical compounds were extracted depending on the solvent type and, of these, 13 compounds were extracted by all three solvents and the total number of extracted compounds was 52 by water extraction, 47 by ethanol extraction, and 43 by methanol extraction (Table 3).

\section{Discussion}


215

216

217

218

219

220

221

222

223

224

225

226

227

228

229

230

231

232

233

234

235

236

237

238

239

240

241

242

243

244

245

246

247

248

249

250

Antibiotic resistance is becoming more common among a larger number of microorganisms, including Candida species, leading to a heightened interest in finding alternative treatments. The secondary metabolites of plants have made them useful for treating a variety of diseases, flavoring foods and products, preserving food, in pesticides, in perfumes and cosmetics, and more recently to inhibit the microbial growth. VA-C leaf extracts have been reported to cause mild and reversible side effects such as headache, acne, nausea, gastrointestinal disturbances, erythematous rash, pruritus, and menstrual disorders. However, no drug interactions have been associated with VA-C leaf extracts (Daniele et al., 2005). Therefore, VA-C leaf extracts (ethanol, methanol, and water) were investigated for their ability to inhibit the growth of three Azoles antibiotic-resistant Candida species: C. ciferrii, C. albicans, and C. tropicalis (Romald et al., 2019; Bhakshu, et al., 2016).

Our results showed that alcohol extracts (methanol and ethanol) and aqueous extract have the ability to inhibit the growth of all tested Candida species. These results are in agreement with Kalhora et al.'s study (2014), which found that the ethanol VA-C leaf extract has the potential to inhibit the growth of $C$. albicans. Our results are also consistent with Maltaş et al., (2010) who observed that the methanol extract of VA-C leaves inhibits the growth of C. albicans. Moreover, we showed that the inhibitory capacity of the solvents varied significantly in descending order of ethanol, then water, then methanol. These results are in line with a recent study conducted by Keikha et al. (2018) who found that VA-C ethanol leaf extract has the highest inhibiting effect against $C$. albicans isolates than water extract. Our results showed a similarity in the inhibitory effect of all extracts with nystatin $(10 \mathrm{mcg})$ as a positive control against $C$. albicans, where the inhibitory effect for the positive control was higher than all extracts against $C$. tropicalis.

We found that MIC showed that the ethanol extracts of VA-C were relatively higher than water and methanol. MIC values were between $12.5 \mu \mathrm{g} / \mathrm{ml}$ and $25 \mu \mathrm{g} / \mathrm{ml}$ for ethanol and represented a dilution of 4 and 3, respectively. For water and methanol the MIC values are specified at $25 \mu \mathrm{g} / \mathrm{ml}$ which represents dilution 3. Our results are similar to those of Keikha et al. (2018) who also found that the ethanol extract of VA-C was more effective than the aqueous extract when the MIC values of ethanol against isolates of Candida species were between 0.78 $\mu \mathrm{g} / \mathrm{ml}$ and $1.56 \mu \mathrm{g} / \mathrm{ml}$, which represent dilution 7 and 8 , respectively. The values of the aqueous extract were between $6.25 \mu \mathrm{g} / \mathrm{ml}$ and $1.562 \mu \mathrm{g} / \mathrm{ml}$, which represent dilutions of 5 and 7 , respectively.

There was a convergence of MFC values, which represents only the three dilutions from 1 to $3(100 \mu \mathrm{g} / \mathrm{ml}$ and $25 \mu \mathrm{g} / \mathrm{ml})$, respectively. The VA-C extract of ethanol was the most influential on $C$. tropicalis with the value of MFC $25 \mu \mathrm{g} / \mathrm{ml}$ and the aqueous extract was less effective on C. albicans, with a value of $100 \mu \mathrm{g} / \mathrm{ml}$.

Peer) reviewing PDF | (2020:07:51312:1:1:NEW 6 Nov 2020) 
251

252

253

254

255

256

257

258

259

260

261

262

263

264

265

266

267

268

269

270

271

272

273

274

275

276

277

278

279

280

281

282
Selection of antibiotics for the treatment of infections is highly influenced by the mechanism of action. Antibiotics classified into either by killing the microbe (microbicidal) or inhibiting its growth (microbistatic) (Etebu and Arikekpar, 2016). Antibiotics with inhibitory effects are usually prescribed to patients who do not have problems with their immune system, while antibiotics with a fatal effect are prescribed for patients with low immunity or severe infections (Davies and Davies, 2010). Candida species are generally opportunistic and affect the group of people with low immunity so antibiotics that are prescribed are generally more effective if they are of the fatal type. Therefore, the inhibitory efficiency of the VA-C extract was estimate using the ratio between MFC and MIC. Our results showed that the ratio of MFC/MIC between two-fold to four-fold have a candidacidal effect (Levison and Levison, 2009). To our best of our knowledge, ours is the first study to establish this finding.

We found that the extracts of VA-C differed in their inhibitory effect according to the type of solvent and this is may be due to the difference in the degree of polarity between the solvent. Water has the highest polarity of 1,000 followed by methanol (0.762) and finally, ethanol (0.654). The compounds extracted by these highly polar solvents differ in quantity and quality (Abubakar and Haque, 2020). Many studies have demonstrated the effect of the solvent type on the inhibitory potential of plant extracts (Aljuraifani 2017; Ababutain 2015).

The GC-MC analysis result revealed that all three VA-C extracts were rich in chemical compounds that act as an anti-inflammatory, anticancer, anti-Alzheimer, anti-diarrheal, antidiabetic, anti-viral, antioxidant, anti-allergic, nematicide, antibacterial, antifungal. These extracts are also used as food preservatives and flavorings, as previously found in other published works (Table 3). Several of these secondary metabolites belong to important chemical groups such as polyphenols, fatty acids, terpenes, terpenoid, steroids, aldehydes, alcohol, and esters. These results are in agreement with a previous study of Keikha et al. (2018), which stated that the VA-C extract was rich in chemical compounds, and the alcoholic extract contained 36 chemical compounds that belong to different chemical groups. Our results showed that the majority of compounds were 4,5Dichloro-1,3-dioxolan-2-one in both ethanol and methanol, 1H-Indene, 2,3-dihydro-1,1,2,3,3pentamethyl in ethanol, Isobutyl 4-hydroxybenzoate in methanol, and Benzoic acid and 4hydroxy- in water. Keikha et al. (2018) found that the majority of compounds in the VA-C ethanol extract were $\alpha$-Pinene, isoterpinolene, caryophyllene, and azulene. The difference in the number of phytochemical compounds may be attributed to the variations among the VA-C genotypes (Karaguzel and Girmen, 2009). 
283

284

285

286

287

288

289

290

291

292

293

294

295

296

297

298

299

300

301

302

303

304

305

306

307

308

309

310

311

312

313

314

315

316

317

318

319

320

321

The inhibitory activity of VA-C extracts maybe attributed to the presence of important bioactive compounds (Abdal Sahib et al., 2019), which may target different structures of the Candida species including the cell wall, cell membrane, and mitochondria enzymes. Some of these compounds may reduce or prevent the virulence factors, including adhesins, enzymes production, germ tubes (Pseudohyphal), biofilm formation, and quorum sensing (de Oliveira Santos et al., 2018; Liu et al., 2017, Sardi et al.,2013). Our results showed the diversity of the compounds extracted from VA-C plant leaves that belong to several effective biochemical compounds with different anticandidal activity, including polyphenols that can destroy the Candida cell membrane leading to permeability of the cell contents (Peralta et al., 2015; Hwang et al., 2011; Hwang et al., 2010), inhibition of mitochondrial enzyme activity in the Candida cell (Yang et al., 2014) and inhibition of the germ tube formation (Seleem et al., 2016). Fatty acids with carbon chains between 10-12 carbons had a good inhibitory effect against Candida species (Ababutain, 2019; Bergsson et al., 2001). Terpenes have been reported to have inhibitory effects against $C$. albicans and may prevent biofilm formation (Pemmaraju et al., 2013). Terpenoids inhibit $C$. albicans cell growth by affecting the membrane and preventing adhesins, biofilm formation, and germ tube formation (Touil et al., 2020; Raut et al., 2013; Zore et al., 2011).

\section{Conclusions}

Our results showed that VA-C leaf extract is rich in bioactive compounds with broad spectrum activity that inhibited all the tested Candida species despite different species. Accordingly, VA-C leaf extracts may inhibit the growth of Candida species in general, compared to antifungals that affect a specific species or a strain of species and require an accurate diagnosis of the Candida isolation to choose the appropriate antifungal. The inhibitory activity of the ethanol solvent was better than methanol and water, which may indicate the importance of choosing the appropriate solvent to extract phytochemicals with high inhibiting effectiveness and in higher quantities. Moreover, our results showed that the extract had a candidacidal effect on test Candida species at low concentrations, which may reduce the side effects of the extract. VA-C leaf extracts are advantageous, and a promising component that can be used to develop an alternative anticandidal agent. Further studies are required to assess the toxicity, genotoxicity and mutagenicity of VA-C extracts and prove their safety for human use.

\section{Acknowledgements}

The authors thank the Director of Basic and Applied Scientific Research Centre (BASR) at Imam Abdulrahman Bin Faisal University, Dammam, Saudi Arabia for her continuous support and encouragement. The authors would like to thank Dr. Ahmed Alsayyah, Dr. Reem AlJindan, and Mrs. Nouf Alromaihi at King Fahd Hospital, Al Khobar, Kingdom of Saudi Arabia for providing us with the microorganisms for testing.

\section{References}


322 Ababutain, I., 2015. Impact of solvent type on antibacterial activities of Lawsonia inermis leaves. 323 J. Food Agric. Environ. 13 (1),51-53.

324 Ababutain, I.M., 2019. Antimicrobial activity and gas chromatography-mass spectrometry (GC325 MS) analysis of Saudi Arabian Ocimum basilicum Leaves Extracts, J. Pure Appl. Microbiol. 13(2), 326 823-833.

327 Ababutain, I.M., Alghamdi, A.I., 2018. Phytochemical analysis and antibacterial activity of Vitex

328

329

330

331

332

333

334

335

336

337

338

339

340

341

342

343

344

345

346

347

348

349

350

351

352

353

354

355

356

357

358

359

360

361

362 agnus-castus L. leaf extracts against clinical isolates. Asia Life Sci. 27(1), 11-20.

Abdal Sahib, A.H., Al-Shareefi, E., Hameed, I.H., 2019. Detection of Bioactive Compounds of Vitex agnus-castus and Citrus sinensis Using Fourier-transform infrared spectroscopic profile and Evaluation of Its Anti-microbial Activity. Indian J. Public. Health Res. Dev.10(1), 954-959.

Abdulrasheed, M., Ibrahim I.H, Luka, A, Maryam, A. A, Hafsat, L, Ibrahim, S, Maigari, F.U., Gidado, M.B., 2019. Antibacterial effect of Cinnamon (Cinnamomum zeylanicum) bark extract on different bacterial isolates. JEMAT. 7(1),16-20.

Abubakar, A.R., Haque M., 2020. Preparation of medicinal plants: Basic extraction and fractionation procedures for experimental purposes. J. Pharm. Bioall. Sci.12,1-10.

Adams, R.P., 2007. Identification of essential oil component by gas chromatography/ mass spectrometry. Allured Publishing Corporation, Carol Stream, Illinois.

Aljuraifani, A., 2017. Impact of solvent types on antimicrobial activities of pumpkin (Cucurbita pepo L.) pulp extracts. Asia Life Sci. 26 (2), 229-235.

Al-Marzoqi, A.H., Hadi, M.Y., Hameed, I.H., 2016. Determination of metabolites products by Cassia angustifolia and evaluate antimicrobial activity. J. Pharmacognosy Phytother. 8(2), 25-48. Al-Salih, D.A., Aziz, F.M., Mshimesh, B.A., Jehad, M.T., 2013. Antibacterial Effects of Vitamin E: in Vitro Study. J. Biotechnol. Res. Center 7(2), 17-23.

Arokiyaraj, S., Perinbam, K., Agastian, P., Kumar M.R., 2009. Phytochemical analysis and antibacterial activity of Vitex agnus-castus. IJGP. 3(2),162-164.

Asdadi, A., Idrissi Hassani L.M., Chebli, B., Moutaj, R., Gharby, S., Harhar, H., Salghi, R., EL Hadek, M. 2014. Chemical composition and antifungal activity of vitex agnus-castus 1. seeds oil growing in Morocco. J. Mater Environ. Sci. 5(3), 823-830.

Bergsson, G., Arnfinnsson, J.H., Steingri'msson, O'., Thormar, H., 2001. In Vitro killing of Candida albicans by fatty acids and monoglycerides. Antimicrob. Agents Chemother. 45(11), 3209-3212.

Bhakshu, L.Md., Ratnam, K.V., Raju, R.R.V., 2016. Anticandidal activity and phytochemical analysis of certain medicinal plants from Eastern Ghats, India. Indian J. Nat. Prod. Resour. 7(1), 25-31.

Bidossi, A., Bortolin, M., Toscano, M., De Vecchi, E., Romanò, C.L., Mattina, R., Drago, L., 2017. In vitro comparison between $\alpha$-tocopheryl acetate and $\alpha$-tocopheryl phosphate against bacteria responsible of prosthetic and joint infections. PLoS One 12(7), e0182323. doi:10.1371/journal. Pone.0182323

Birkbeck, T.H., Reid, H.I., Darde, B., Grant, A.N., 2006. Activity of bronopol (Pyceze $\left.{ }^{\circledR}\right)$ against bacteria cultured from eggs of halibut, Hippoglossus hippoglossus and cod, Gadus morhua. Aquaculture 254, 125-128. 
363 Brandt, M.E., Lockhart, S.R., 2012. Recent Taxonomic Developments with Candida and Other 364 Opportunistic Yeasts. Curr. Fungal Infect. Rep. 6(3), 170-177.

365 Brickell, C., Zuk, J.D., 1997. A-Z Encyclopedia of garden plants. New York, United States, The 366 American Horticultural Society, DK Publishing Inc. 1095 p.

367 Carlomagno, G., Unfer, V., 2011. Inositol safety: clinical evidences. Eur. Rev. Med. Pharmacol. 368 Sci. 15, 931-936.

369 Chatelon, J., Cortegiani, A., Hammad, E., Cassir, N., Leone, M., 2019. Choosing the Right 370 Antifungal Agent in ICU Patients. Adv. Ther. 36(12), 3308-3320.

371 Cheng, S-S., Chung, M-J., Lin, C-Y., Wang, Y-N., Chang, S-T., 2012. Phytochemicals from 372 Cunninghamia konishii Hayata act as antifungal agents. J. Agric. Food Chem. 60(1), 124-128.

373 da Rocha, A. B., Lopes, R. M., Schwartsmann, G. 2001. Natural products in anticancer therapy. 374 Curr. Opin. Pharmacol. 1, 364-369. doi: 10.1016/s1471-4892(01)00063-7.

375 Daniele, C., Coon, J.T., Pittler, M.H., Ernst. E., 2005. Vitex agnus castus: A systematic review 376 of adverse events. Drug Saf. 28(4), 319-332.

377 Davies, J., Davies, D., 2010. American Society for Microbiology. All Rights Reserved. Origins 378 and Evolution of Antibiotic Resistance. Microbiol. Mol. Biol. R. 74(3), 417-433.

379 de Oliveira Santos, G.C., Vasconcelos, C.C., Lopes, A.J.O., de Sousa Cartágenes, M.dS., Filho, 380 A.K.D.B., do Nascimento, F.R.F., Ramos, R.M., Pires, E.R.R.B., de Andrade, M.S., Rocha, 381 F.M.G., de Andrade, M.C., 2018. Candida Infections and Therapeutic Strategies: Mechanisms of 382 Action for Traditional and Alternative Agents. Front. Microbiol. 9,1351. doi: 383 10.3389/fmicb.2018.01351.

384 Dervishi-Shengjergji, D., Vilma, P., Xhulieta, H., Aurel, N., Blerta, K., 2014. Antibacterial activity 385 and chemical composition of Vitex agnus castus fruits essential oils from Mbishkodra, Albania. 386 JIEAS. 9(4), 521-424.

387 Drobnica, L., Sturdík, E.,1980. Antimicrobial Activity of 2-vinylfuran Derivatives. Folia 388 Microbiol (Praha). 25(6), 467-75.

389 Eryigit, T., Çig, A., Okut, N., Yildirim, B., Ekici, K., 2015. Evaluation of chemical composition 390 and antimicrobial activity of Vitex agnus castus L. fruits' essential oils from West Anatolia, 391 Turkey. J. Essent. Oil Bear Plants 18, 208-214.

392 Eseyin, O.A., Sattar M.A., Rathore, H.A., Aigbe,F., Afzal S., Ahmad, A., Lazhari, M., Akthar, S., 393 2018. GC-MS and HPLC profiles of phenolic fractions of the leaf of Telfairia occidentalis. Pak. J. 394 Pharm. Sci. 31(1), 45-50.

395 Etebu, E., Arikekpar, I., 2016. Antibiotics: Classification and mechanisms of action with emphasis 396 on molecular perspectives. Int. J. Appl. Microbiol. Biotechnol. Res. 4, 90-101.

397 Ganapaty, S., Vidyadhar. K.N., 2005. Phytoconstituents and biological activities of Vitex: A 398 review. JNR. 5, 75-95.

399 Ghannadi, N., Bagherinejad, M.R., Abedi, D., Jalali, M., Absalan, B., Sadeghi, N., 2012. 400 Antibacterial activity and composition of essential oils from Pelargonium graveolens L' Herit. and 401 Vitex agnus-castus L. Iran. J. Microbiol. 4(4), 171-176.

402 Ghimire, G.P., Thuan, N.H., Koirala, N., Sohng, J.K., 2016. Advances in biochemistry and 403 microbial production of squalene and its derivatives. J. Microbiol. Biotechnol. 26(3), 441-451. 
404 Huntley, N. F., Patience, J. F., 2018. Xylose: absorption, fermentation, and postabsorptive 405 metabolism in the pig. J. Anim. Sci. Biotechno. 9(4), DOI 10.1186/s40104-017-0226-9.

406 Hwang, B., Cho, J., Hwang, I.-S., Jin, H.-G., Woo, E.-R., Lee, D. G., 2011. Antifungal activity of 407 lariciresinol derived from Sambucus williamsii and their membrane-active mechanisms in Candida 408 albicans. Biochem. Biophys. Res. Commun. 410(3), 489-493.

409 Hwang, B., Lee, J., Liu, Q.-H., Woo, E.-R., Lee, D. G.,2010. Antifungal effect of (+)-pinoresinol 410 isolated from Sambucus williamsii. Molecules 15(5), 3507-3516, 2010.

411 Ibrahim, I.S., Ali, M., Zage, A.U., 2016. Phytochemistry of methanolic and aqueous extracts of 413 Eilstalyptus camaldulensis leaves, seeds and stem back. Int J Advan.Academic Res. Sci. 2, 75-80. 414 Jegadeeswari, P., Nishanthini, A., Muthukumarasamy. S., Mohan. V.R. 2012. GC-MS analysis of 415 bioactive components of Aristolochia krysagathra (Aristolochiaceae). J. Curr. Chem. Pharm. Sci. $416 \quad 2,226-232$.

417 Johny, A.K., Darre, M.J., Donoghue, A.M., Donoghue, D.J., Venkitanarayanan, K., 2010. 418 Antibacterial effect of trans-cinnamaldehyde, eugenol, carvacrol, and thymol on Salmonella 419 enteritidis and Campylobacter jejuni in chicken cecal contents in vitro. J. Appl. Poultry Res. 19 420 (3), 237-244.

421 Joller, C., De Vrieze, M., Moradi, A., Fournier, C., Chinchilla, D., L'Haridon, F., Bruisson, S., 422 Weisskopf, L., 2020. S-methyl Methanethiosulfonate: Promising Late Blight Inhibitor or Broad

423

425

426

427

428

429

430

431

432

433

434

435

436

437

438

439

440

441

442

443

444

445

Rettgegs Toxin? Pathogens 9(6), 496 doi.org/10.3390/pathogens9060496.

Kalhoro, M.A., Farheen, S., Aqsa, N.U., 2014. The antimicrobial activity of ethanol extract of Vitex agnus-castus. Am. Int. J. Contemp. Res. 1(1), 47-50.

Karthikeyan, S. C., Velmurugan, S., Donio, M. B., Michaelbabu, M., Citarasu, T., 2014. Studies on the antimicrobial potential and structural characterization of fatty acids extracted from Sydney rock oyster Saccostrea glomerata. Ann. Clin Microb. Anti. 13, 332. doi.org/10.1186/s12941-0140057-x

Karaguzel, O., Girmen, B., 2009. Morphological variations of chaste tree (Vitex agnus-castus) genotypes from southern Anatolia, Turkey, New Zeal. J. Crop. Hort. 37(3), 253-261.

Katiraee, F., Mahmoudi, R., Tahapour, K., Hamidian, G., Emami, S.J., 2015. Biological properties of Vitex agnus-castus essential oil (phytochemical component, antioxidant and antifungal activity). Biotechnol. Health. Sci. 2(2), 267-97.

Keikha, N., Shafaghat, M., Mousavia, S.M., Moudi, M.,Keshavarzi, F., 2018. Antifungal effects of ethanolic and aqueous extracts of Vitex agnus-castus against vaginal isolates of Candida albicans. Curr. Med. Mycol. 4(1), 1-5.

Kim, G-Y., Jeon J-S., Jae Kyung Kim, J.K., 2016. Isolation Frequency Characteristics of Candida Species from Clinical Specimens. Mycobiology 44(2), 99-104.

Kirti, K., Amita, S., Priti, S., Mukesh Kumar, A., Jyoti. S., 2014. Colorful World of Microbes: Carotenoids and Their Applications. Adv. Biol. 2014, 1-13.

Koehler, P., Stecher. M., Cornely O.A., Koehler. D., Vehreschild, M.J.G.T., Bohlius. J., Wisplinghoff, H., Vehreschild, J.J., 2019. Morbidity and mortality of candidaemia in Europe: an epidemiologic meta-analysis. Clin. Microbiol. Infect. 25(10), 1200-1212.

Peer] reviewing PDF | (2020:07:51312:1:1:NEW 6 Nov 2020) 
446 Kumar, R.N., Vasantha, K., Mohan, V.R., 2014. GC-MS analysis of bioactive components of 447 tubers of Ruellia tuberosa L. (Acanthaceae). Am. J. Phytomed. Clin. Ther. 2(2), 209-216.

448 Kumaravel, S., Muthukumaran, P., Shanmugapriya, K., 2017. Chemical composition of Trigonella 449 foenumg-raecum through gas chromatography mass spectrometry analysis. J. Med. Plants Stud. 5, $450 \quad 1-3$.

451 Lamba, A., 2007. Antimicrobial activities of aldehydes and ketones produced during rapid 452 volatilization of biogenic oils. Masters Theses.

453 Levison M.E., Levison J.H., 2009. Pharmacokinetics and pharmacodynamics of antibacterial 454

455

456 agents. Infect. Dis. Clin. North Am. 23(4), 791-9.

457 Liu, X., Ma, Z., Zhang, J., Yang. L., 2017. Antifungal compounds against Candida infections from traditional Chinese medicine. BioMed Res. Int. 2017, 1-12. doi.org/10.1155/2017/4614183

458 Ma, K., Thomason, L.A., McLaurin, J., 2012. Scyllo-Inositol, preclinical, and clinical data for Alzheimer's disease. Adv. Pharmacol. 64,177-212.

460 Madan R.K., Levitt J., 2014. A review of toxicity from topical salicylic acid preparations. J. Am. Acad. Dermatol. 70(4), 788-92.

462 Maltaş, E., Uysal, A., Yıldız, S., Durak, Y., 2010. Evaluation of antioxidant and antimicrobial activity of Vitex agnus castus L. Fresenius Environ. Bull. 19, 3094-3099. McDonnell, G., 2009. Sterilization and Disinfection. In Encyclopedia of Microbiology, $3^{\text {rd }}$ Edition, Moselio Schaechter (Editor), Academic press, Elsevier Ltd, 529-548. Miceli, M.H., Diaz, J.A., Lee, S.A., 2011. Emerging opportunistic yeast infections. Lancet. Infect. Dis. 11, 142-151.

467 Miguel, V., Lestard, M.E.D., Tuttolomondo, M.E., Díaz, S.B., BenAltabef, A., Puiatti, M., Pierini, 468 A.B., 2016. Molecular view of the interaction of S-methyl methane-thiosulfonate with DPPC 469 bilayer. Biochim. Biophys. Acta. Biomembr. 1858(1), 38-46. Mincea, M.M., Lupşa, I.R., Cinghiţă, D.F., Radovan, C.V., Talpos, I., Ostafe, V., 2009. 471 Determination of methylparaben from cosmetic products by ultraperformance liquid 472 chromatography. J. Serb. Chem. Soc. 74 (6), 669-676.

473 Naragani, K., Mangamuri, U., Muvva, V., Poda, S., Munaganti, R.K., 2016. antimicrobial potential 474 of streptomyces cheonanensis vuk-a from mangrove origin. Int. J. Pharm. Pharm. Sci. 8(3), 53-57. 475 National Committee for Clinical Laboratory Standards (NCCLS), 1993. Performance Standards 476 for Antimicrobial Disk Susceptibility Tests. Approved Standard, NCCLS Document M2-A5, 477 National Committee for Clinical Laboratory Standards, Wayne, Pennsylvania, USA, 13(24), 35.

478 National Committee for Clinical Laboratory Standards (NCCLS), 1997. Performance Standards 479 for Antimicrobial Disk Susceptibility Tests. Approved Standard M2-A6. National Committee for 480 Clinical Laboratory Standards, Wayne, Pennsylvania, USA, 17(1).

481 Neeraj, Vasudeva, N., Sharma, S., 2019. Chemical composition of Fagopyrum 482 esceulentum Moench seed through GC-MS. Int. J. Pharm. Sci. Res. 10(5), 2392-2396. 
483 Neves, R.C.S., da Camara, C.A.G., 2016. Chemical composition and acaricidal activity of the 484 essential oils from Vitex agnus-castus L. (Verbenaceae) and selected monoterpenes. Annals of the 485 Brazilian Academy of Sciences. An. Acad. Bras. Cienc. 88(3), 1221-1233.

486 Niroumand, M.C., Heydarpour, F., Farzaei, M.H., 2018. Pharmacological and therapeutic effects 487 of Vitex agnus-castus L.: A review. Phcog. Rev.12,103-14.

488 Okoye, N.N., Ajaghaku, D.L., Okeke, H.N., Ilodigwe, E.E., Nworu, C.S., Okoye, F.B. 2014. Beta489 Amyrin and alpha-amyrin acetate isolated from the stem bark of Alstonia boonei display profound 490 anti-inflammatory activity. Pharm. Biol. 52(11), 1478-14786.

491 Olajuyigbe, O.O., Onibudo, T.E., Coopoosamy, R.M., Ashafa, A.O.T., Afolayan, A.J., 2018. 492 Bioactive compounds and in vitro antimicrobial activities of ethanol stem bark extract of 493 Trilepisium madagascariense DC. Int. J. Pharmacol.14(7), 901-912

494 Omura, S., Pyl, D.V.D., Inokoshi, J., Takahashi, Y., Takeshima, Y., 1993. Pepticinnaminsnew 495 farnesyl-protein transferase inhibitors produced by an actinomycete I. Producingstrain, 496 fermentation, isolation and biological activity. J. Antibiot. 46, 222-228.

497 Ovesná, Z., Vachálková, A., Horváthová. K., 2004. Taraxasterol and beta-sitosterol: new naturally 498 compounds with chemoprotective/chemopreventive effects. Neoplasma 51(6), 407-414.

499 Özçelik, B., Kartal, M., Orhan, I., 2011. Cytotoxicity, antiviral and antimicrobial activities of 500 alkaloids, flavonoids, and phenolic acids. Pharm. biol. 49(4), 396-402.

501 Pandey, A., Tripathi, S., 2014. Concept of standardization, extraction and pre phytochemical 502 screening strategies for herbal drug. J. Pharmacogn. Phytochem. 2 (5), 115-119.

503 Paramythiotou, E., Frantzeskaki, F., Flevari, A., Armaganidis, A., Dimopoulos, G., 2014. Invasive 504 Fungal Infections in the ICU: How to Approach, How to Treat. Molecules 19(1),1085-119.

505 Pemmaraju, S.C., Pruthi, P.A., Prasad, R., Pruthi, V., 2013. Candida albicans biofilm inhibition 506 by synergistic action of terpenes and fluconazole. Indian J. Exp. Biol. 51, 1032-1037.

507 Peralta, M. A., Da Silva, M. A., Ortega, M. G., Cabrera, J. L., Paraje, M. G., 2015. Antifungal 508 activity of a prenylated flavonoid from Dalea elegans against Candida albicans biofilms. 509 Phytomedicine, 22(11), 975-980.

510 Rani, A., Sharma, A., 2013. The genus Vitex: A review. Pharmacogn Rev. 7(14), 1-5.

511 Raut, J.S., Shinde, R.B., Chauhan, N.M., Karuppayil, S.M., 2013. Terpenoids of plant origin 512 inhibit morphogenesis, adhesion, and biofilm formation by Candida albicans. Biofouling 513 29(1), 87-96.

514 Rodrigues, C.F., Rodrigues, M.E., Henriques, M., 2019. Candida sp. Infections in Patients with 515 Diabetes Mellitus. J. Clin. Med. 8(1): 76. doi: 10.3390/jcm8010076

516 Romald, P.N., Sridharan, K.S., Mohanty, S., Anupma Jyoti Kindo, A.J., 2019. Rare isolate of 517 Stephanoascus ciferrii from the aural discharge of post-mastoidectomy patient-A case report. J. 518 Clin. Diagn. Res. 13(3), 1-3.

519 Sardi, J.C.O., Scorzoni, L., Bernardi, T., Fusco-Almeida A.M., Mendes Giannini M. J. S., 2013. 520 Candida species: current epidemiology, pathogenicity, biofilm formation, natural antifungal 521 products and new therapeutic options. J. Med. Microbiol. 62, 10-24.

522 Saud, R., Pokhrel, S., Yadav, P.N., 2019. Synthesis, characterization and antimicrobial activity of 523 maltol functionalized chitosan derivatives, Journal of Macromolecular Science, Part A, DOI: $52410.1080 / 10601325.2019 .1578616$. 
525 Seleem, D., Benso, B., Noguti, J., Pardi, V., Murata, R.M., 2016. In vitro and in vivo antifungal 526 activity of lichochalcone-A against candida albicans biofilms. PLoS ONE, 11(6), e0157188. 527 doi:10.1371/ journal. pone. 0157188 .

528 Sermakkani, M., Thangapandian, V., 2012. GC-MS analysis of Cassia italica leaf methanol 529 extract. Asian J. Pharm. Clin. Res. 5(2), 90-4.

530 Shahina, P., Shahzad, A., Upadhyaya, P., Yadav, V. 2016. Gas chromatography-mass 531 spectrometry analysis of methanolic leaf extract of Cassia angustifolia Vahl. Asian J. Pharm. Clin.

532 Res. 9, 111-6.

533 Sharma, V., Singh, G., Kaur, H., Saxena, A.K., Ishar, M.P., 2012. Synthesis of $\beta$-ionone derived 534 chalcones as potent antimicrobial agents. Bioorg. Med. Chem. Lett. 22(20), 6343-6.

535 Shibula, K., Velavan, S., 2015. Determination of phytocomponents in methanolic extract of 536 Annona muricata leaf using GC-MS technique. Int. J. Pharmacog. Phytochem. Res. 7, 1251-5.

537 Solanki, S., Singh, A., Sood, H., 2018. GC analysis of invitro developed shoots of Stevia 538 rebaudiana through rapid tissue culture. International Conference on New Horizons in Green 539 Chemistry \& Technology (ICGCT) 2018.

540 Available at SSRN: http://dx.doi.org/10.2139/ssrn.3298672

541 Statistical Packages for Software Sciences (SPSS). 2013. version 21.0 Armonk, New York, IBM 542 Corporation. Released.

543 Tan, K.H., Nishida, R., 2012. Methyl eugenol: Its occurrence, distribution, and role in nature, 544 especially in relation to insect behavior and pollination. J. Insect. Sci. 12(1), 1-60.

545 Tolstikov, G.A., Flekhter, O.B., Shul'ts, E.E., Baltin, L.A., Tolsikov, A.G., 2005. Betulin and its 546 derivatives. chemistry and biological activity. Khim. Interes. Ust. Razv. 13, 1-30.

547 Touil, H.F.Z., Boucherit, K., Boucherit-Otmani, Z., Kohder, G., Madkour, M., Soliman, 548 S.S.M. 2020. Optimum inhibition of amphotericin-B-Resistant Candida albicans strain in 549 single- and mixed-species biofilms by Candida and non-Candida terpenoids. Biomolecules 550 10(2), 342. doi: 10.3390/biom10020342

551 Treasurer, W. Cochrane, E., Grant, A., 2005. Surface disinfection of cod gadus morhua and 552 haddock melanogrammus aeglefinus eggs with bronopol, aquaculture 250(1-2), 27-35.

553 Tripathi, N., Kumar, S., Singh, R., Singh, C.J., Singh, P., 2013. Varshney V.K. Isolation and 554 Identification of $\gamma$-sitosterol by GC-MS from Roots of Girardinia heterophylla. OJC. 29(2), 7055557.

556 Tyagi, T., Agarwal, M., 2017. Phytochemical screening and GCMS analysis of bioactive 557 constituents in the ethanolic extract of Pistia stratiotes L. and Eichhornia crassipes (Mart.) solms. 558 J. Pharmacogn. Phytochem. 6(1), 195-206.

559 Ulukanli, Z., Çenet, M., Öztürk, B., Bozok, F., Karabörklü, S., Demirci, S.C., 2015. Chemical 560 characterization, phytotoxic, antimicrobial and insecticidal activities of Vitex agnus-castus: 561 Essential oil from East Mediterranean Region. J. Essent. Oil-Bear. Plants. 18(6), 1500-1507.

562 Wei, J.H., Yin, X., Welander, P.V., 2016. Sterol Synthesis in Diverse Bacteria. Front Microbiol. 563 7,990. doi:10.3389/fmicb.2016.00990.

564 World Health Organization. (WHO). 2002. Monographs on Selected Medicinal Plants. 2, 55-65. 
565 Yang, S., Fu, Y., Wu X., Zhou, Z., Xu, J., Zeng, X., Kuang, N., Zeng, Y., 2014. Baicalin prevents 566 Candida albicans infections via increasing its apoptosis rate. Biochem. Biophys. Res. Commun. 567 451(1), 36-41.

568 Yilar, M., Bayan, Y., Onaran, A., 2016. Chemical Composition and Antifungal Effects of Vitex 569 agnus-castus L. and Myrtus communis L. Plants. Not. Bot. Horti. Agrobo. 44(2), 466-471.

570 Zore, G.B., Thakre, A.D., Jadhav, S., Karuppayil, S.M., 2011. Terpenoids inhibit Candida 571 albicans growth by affecting membrane integrity and arrest of cell cycle. Phytomedicine 572 18(13), 1181-90.

573 


\section{Table $\mathbf{1}$ (on next page)}

Table 1 . Anticandidal activity of VAC leaves extract at concentration of $20 \%$ by using well diffusion assay

${ }^{*} \mathrm{P}$-value has been calculated using one-way Anova. ${ }^{* *}$ Significant at $p<0.01$ level. ND, not identified 


\begin{tabular}{|c|c|c|c|c|c|c|}
\hline \multirow[b]{2}{*}{$\begin{array}{l}\text { Candida } \\
\text { species }\end{array}$} & \multicolumn{6}{|c|}{ Zone of inhibition $(\mathrm{mm})$ Mean \pm SD } \\
\hline & $\begin{array}{c}\text { Nystatin } \\
(10 \mathrm{mcg})\end{array}$ & $\begin{array}{c}\text { negative } \\
\text { control }\end{array}$ & Ethanol & Water & Methanol & P-value * \\
\hline C. tropicalis & $\begin{array}{c}11.0 \pm \\
1.00\end{array}$ & 0 & $7.50 \pm 0.50$ & $\begin{array}{c}5.67 \pm \\
0.29\end{array}$ & $\begin{array}{c}5.33 \pm \\
0.29\end{array}$ & $0.01^{* *}$ \\
\hline C. albicans & $\begin{array}{c}5.83 \pm \\
0.29\end{array}$ & 0 & $5.83 \pm 0.29$ & $\begin{array}{c}5.00 \pm \\
0.50\end{array}$ & $\begin{array}{c}5.00 \pm \\
0.50\end{array}$ & $0.047^{* *}$ \\
\hline C. ciferrii & ND & 0 & $4.33 \pm 0.58$ & $\begin{array}{c}3.33 \pm \\
0.29\end{array}$ & $\begin{array}{c}3.33 \pm \\
0.29\end{array}$ & $0.037^{* *}$ \\
\hline P-value & $0.01 * *$ & - & $0.01 * *$ & 0.01 ** & $0.01^{* *}$ & -- \\
\hline
\end{tabular}




\section{Table 2 (on next page)}

Table 2. Minimal Inhibitory Concentration (MIC) $\mu \mathrm{g} / \mathrm{ml}$ and Minimal Fungicidal Concentration (MFC) $\mu \mathrm{g} / \mathrm{ml}$ and their ratio of VA-C leaves extracts.

*Ratio MFC/MIC 


\begin{tabular}{lccccccccc}
\hline & \multicolumn{3}{c}{ Ethanol } & \multicolumn{3}{c}{ Water } & \multicolumn{3}{c}{ Methanol } \\
\hline $\begin{array}{l}\text { Candida } \\
\text { species }\end{array}$ & MIC & MFC & Ratio* & MIC & MFC & Ratio* & MIC & MFC & Ratio* \\
\hline C. tropicalis & 12.5 & 25 & 2 & 25 & 50 & 2 & 25 & 50 & 2 \\
C. albicans & 25 & 50 & 2 & 25 & 50 & 2 & 25 & 100 & 4 \\
C. ciferrii & 25 & 50 & 2 & 25 & 50 & 2 & 25 & 50 & 2 \\
\hline
\end{tabular}




\section{Table 3(on next page)}

Table 3. GC-MS analysis of VA-C leaves extracts, their molecular formula, nature and biological activities. 


\begin{tabular}{|c|c|c|c|c|c|c|}
\hline \multirow[b]{2}{*}{ No } & \multirow[b]{2}{*}{ Compound name } & \multicolumn{3}{|c|}{ Peak Area $\%$} & \multirow{2}{*}{$\begin{array}{l}\text { Molecular } \\
\text { Formula }\end{array}$} & \multirow{2}{*}{$\begin{array}{l}\text { Compound nature and } \\
\text { biological activities }\end{array}$} \\
\hline & & $\begin{array}{c}\text { Ethan } \\
\text { ol }\end{array}$ & $\begin{array}{l}\text { Meth } \\
\text { anol }\end{array}$ & water & & \\
\hline 1 & $\begin{array}{l}\text { 4,5-Dichloro-1,3- } \\
\text { dioxolan-2-one }\end{array}$ & 7.43 & 7.45 & 1.39 & $\mathrm{C}_{3} \mathrm{H}_{2} \mathrm{Cl}_{2} \mathrm{O}_{3}$ & No report was found. \\
\hline 2 & $\begin{array}{l}\text { Benzoic acid, 4- } \\
\text { hydroxy- }\end{array}$ & 2.13 & 3.95 & 5.99 & $\mathrm{C}_{7} \mathrm{H}_{6} \mathrm{O}_{3}$ & $\begin{array}{l}\text { Phenolic compounds (Eseyin et } \\
\text { al., 2018). }\end{array}$ \\
\hline 3 & $\begin{array}{l}\text { 5- } \\
\text { Hydroxymethylfurfur } \\
\text { al }\end{array}$ & 1.18 & 1.61 & 0.82 & $\mathrm{C}_{6} \mathrm{H}_{6} \mathrm{O}_{3}$ & $\begin{array}{l}\text { Organic compound Antioxidant } \\
\text { and Antiproliferative (Ibrahim et } \\
\text { al., 2016). }\end{array}$ \\
\hline 4 & Phenol & 1.12 & 1.73 & 1.41 & $\mathrm{C}_{6} \mathrm{H}_{5} \mathrm{OH}$ & $\begin{array}{l}\text { Phenolic compound, antiviral, } \\
\text { antibacterial and antifungal } \\
\text { activities (Özçelik et al., 2011). }\end{array}$ \\
\hline 5 & $\begin{array}{l}\text { 4H-Pyran-4-one, 2,3- } \\
\text { dihydro-3,5- } \\
\text { dihydroxy- }\end{array}$ & 0.75 & 0.82 & 1.41 & $\mathrm{C}_{6} \mathrm{H}_{8} \mathrm{O}_{4}$ & $\begin{array}{l}\text { Flavonoids, Anti-inflammatory, } \\
\text { analgesic, antimicrobial activity } \\
\text { (Neeraj et al., 2019). }\end{array}$ \\
\hline 6 & Catechol & 0.50 & 0.57 & 1.14 & $\mathrm{C}_{6} \mathrm{H}_{4}(\mathrm{OH})_{2}$ & $\begin{array}{l}\text { Polyhydric phenol, antiviral, } \\
\text { antimicrobial activities (Özçelik } \\
\text { et al., 2011). }\end{array}$ \\
\hline 7 & $\begin{array}{l}\text { Benzeneacetaldehyd, } \\
\text { alpha-methyl- }\end{array}$ & 0.35 & 0.65 & 1.26 & $\mathrm{C}_{9} \mathrm{H}_{10} \mathrm{O}$ & Hydrotropic aldehyde. \\
\hline 8 & $\begin{array}{l}\text { Benzeneacetic acid, } \\
\text { 4-hydroxy3-methoxy, }\end{array}$ & 0.39 & 0.38 & 0.58 & $\mathrm{C}_{10} \mathrm{H}_{12} \mathrm{O}_{4}$ & No report was found. \\
\hline 9 & Pentanal & 0.10 & 0.16 & 0.88 & $\mathrm{C}_{5} \mathrm{H}_{10} \mathrm{O}$ & $\begin{array}{l}\text { alkyl aldehyde, Inhibition } \\
\text { bacteria (Lamba, 2007). }\end{array}$ \\
\hline 10 & Squalene & 0.13 & 0.37 & 0.40 & $\mathrm{C}_{30} \mathrm{H}_{50}$ & $\begin{array}{l}\text { Terpenoid, Anticandidal activity, } \\
\text { antioxidant, anti-inflammatory, } \\
\text { and anticancer agent (Ghimire et } \\
\text { al., 2016; Zore et al., 2011). }\end{array}$ \\
\hline 11 & Maltol & 0.06 & 0.14 & 0.77 & $\mathrm{C}_{6} \mathrm{H}_{6} \mathrm{O}_{3}$ & $\begin{array}{l}\text { Antimicrobial activity } \\
\text { (Saud et al., 2019). }\end{array}$ \\
\hline 12 & $\begin{array}{l}1 \mathrm{H}- \\
\text { Benzocyclohepten-7- } \\
\text { ol,2,3,4,4a,5,6,7,8- }\end{array}$ & 0.36 & 0.12 & 0.11 & $\mathrm{C}_{15} \mathrm{H}_{26} \mathrm{O}$ & $\begin{array}{l}\text { Sesquiterpenids (Solaki et al., } \\
\text { 2018). }\end{array}$ \\
\hline 13 & n-Hexadecanoic acid & 0.70 & 0.56 & 0.96 & $\mathrm{C}_{16} \mathrm{H}_{32} \mathrm{O}_{2}$ & $\begin{array}{l}\text { Palmitic saturated Fatty acid } \\
\text { ester, antimicrobial, antitumor } \\
\text { activities, antioxidant, pesticide, } \\
\text { nematicide, antiandrogenic and } \\
\text { hypochloesterolemi (Tyagi and } \\
\text { Agarwal., 2017; Karthikeyan et } \\
\text { al., 2014; Sermakkani and } \\
\text { Thangapandian, 2012;). }\end{array}$ \\
\hline 14 & $\begin{array}{l}\text { 3,5-Octadienoic acid, } \\
\text { 7-hydroxy-2-methyl }\end{array}$ & 0.85 & 1.04 & - & $\mathrm{C}_{9} \mathrm{H}_{14} \mathrm{O}_{3}$ & No report was found. \\
\hline 15 & Eugenol & 0.39 & 0.36 & - & $\mathrm{C}_{10} \mathrm{H}_{12} \mathrm{O}_{2}$ & $\begin{array}{l}\text { Phenolic compounds, } \\
\text { antimicrobial activity, } \\
\text { insecticide nematicide and food } \\
\text { additive } \\
\text { (Tan and Nishida, 2012; Johny }\end{array}$ \\
\hline
\end{tabular}




\begin{tabular}{|c|c|c|c|c|c|c|}
\hline & & & & & & et al., 2010). \\
\hline 16 & 1,2,3-Benzenetriol & 0.56 & 0.67 & - & $\mathrm{C}_{6} \mathrm{H}_{6} \mathrm{O}_{3}$ & No report was found. \\
\hline 17 & $\begin{array}{l}\text { Propylphosphonic } \\
\text { acid, di(2-ethylhexyl) } \\
\text { ester }\end{array}$ & 2.57 & 1.18 & - & $\mathrm{C}_{21} \mathrm{H}_{40} \mathrm{O}_{4}$ & Ester. \\
\hline 18 & Methylparaben & 0.39 & 0.28 & - & $\mathrm{C}_{8} \mathrm{H}_{8} \mathrm{O}_{3}$ & $\begin{array}{l}\text { Antimicrobial activity, food } \\
\text { preservative, added to cosmetic } \\
\text { products, and pharmaceutical } \\
\text { products (Mincea et al., 2009). }\end{array}$ \\
\hline 19 & $\begin{array}{l}1 \mathrm{H} \text { - } \\
\text { Cycloprop[e]azulen- } \\
\text { 7-ol, decahydro- } \\
\text { 1,1,7-trimethyl-4- } \\
\text { methylene }\end{array}$ & 1.21 & 1.04 & - & $\mathrm{C}_{15} \mathrm{H}_{24} \mathrm{O}$ & No report was found. \\
\hline 20 & Triacetin & 0.19 & 0.27 & - & $\mathrm{C}_{9} \mathrm{H}_{14} \mathrm{O}_{6}$ & $\begin{array}{l}\text { Triester of glycerin and acetic } \\
\text { acid. }\end{array}$ \\
\hline 21 & $\begin{array}{l}\text { 5-(1-Isopropenyl-4,5- } \\
\text { dimethylbicyclo } \\
{[4.3 .0]}\end{array}$ & 1.13 & 0.87 & - & $\mathrm{C}_{22} \mathrm{H}_{36} \mathrm{O}_{2}$ & No report was found. \\
\hline 22 & $\begin{array}{l}\text { 2,4-Cholestadien-1- } \\
\text { one }\end{array}$ & 1.72 & 0.96 & - & $\mathrm{C}_{27} \mathrm{H}_{42} \mathrm{O}$ & No report was found. \\
\hline 23 & Phytol & 3.31 & 1.81 & - & $\mathrm{C}_{20} \mathrm{H}_{40} \mathrm{O}$ & $\begin{array}{l}\text { Diterpene, antiviral and } \\
\text { antimicrobial activities (Özçelik } \\
\text { et al., 2011). }\end{array}$ \\
\hline 24 & $\begin{array}{l}9,12,15- \\
\text { Octadecatrienoic } \\
\text { acid, }(Z, Z, Z)-\end{array}$ & 1.18 & 0.90 & - & $\mathrm{C}_{18} \mathrm{H}_{30} \mathrm{O}_{2}$ & $\begin{array}{l}\text { Linolenic Omega-3 } \\
\text { polyunsaturated fatty acid, anti- } \\
\text { inflammatory (Sermakkani and } \\
\text { Thangapandian, 2012). }\end{array}$ \\
\hline 25 & Cedran-diol, $(8 \mathrm{~S}, 14)-$ & 0.13 & 0.52 & - & $\mathrm{C}_{15} \mathrm{H}_{26} \mathrm{O}_{2}$ & No report was found. \\
\hline 26 & $\begin{array}{l}3,7,11,15- \\
\text { Tetramethyl-2- } \\
\text { hexadecen-1-ol }\end{array}$ & 1.11 & 1.34 & - & $\mathrm{C}_{20} \mathrm{H}_{40} \mathrm{O}$ & $\begin{array}{l}\text { Terpene Alcohol, antimicrobial, } \\
\text { antioxidant, anti-inflammatory } \\
\text { and flavoring agent (Shibula and } \\
\text { Velavan, 2015; Jegadeeswari et } \\
\text { al., 2012; Sermakkani and } \\
\text { Thangapandian, 2012). }\end{array}$ \\
\hline 27 & $\begin{array}{l}\text { Spiro }[4.5] \text { dec-9-en- } \\
1 \text {-ol,1,6,6,10- } \\
\text { tetramethyl }\end{array}$ & 0.54 & 0.39 & - & $\mathrm{C}_{14} \mathrm{H}_{24} \mathrm{O}$ & No report was found. \\
\hline 28 & $\begin{array}{l}\text { Dodeca-1,6-dien-12- } \\
\text { ol, 6,10-dimethyl }\end{array}$ & 1.57 & 1.57 & - & $\mathrm{C}_{14} \mathrm{H}_{26} \mathrm{O}$ & No report was found. \\
\hline 29 & Octadecanoic acid & 0.51 & - & 0.22 & $\mathrm{C}_{17} \mathrm{H}_{35} \mathrm{CO}_{2} \mathrm{H}$ & Stearic saturated fatty acid. \\
\hline 30 & $\begin{array}{l}\text { Benzenediazonium, } \\
\text { 2-hydroxy-, } \\
\text { hydroxide, i }\end{array}$ & 0.86 & - & 1.17 & $\mathrm{C}_{6} \mathrm{H}_{5} \mathrm{~N}_{2} \mathrm{O}$ & No report was found. \\
\hline 31 & Vitamin E & - & 0.39 & 0.36 & $\mathrm{C}_{29} \mathrm{H}_{50} \mathrm{O}_{2}$ & $\begin{array}{l}\text { Lipid, antibacterial, anti- } \\
\text { alzheimer, antiaging and } \\
\text { antioxidant (Kumaravel et al., } \\
\text { 2017; Al-Marzoqi et al., 2016; } \\
\text { Shahina et al., 2016; Al-Salih et } \\
\text { al.,2013). }\end{array}$ \\
\hline
\end{tabular}




\begin{tabular}{|c|c|c|c|c|c|c|}
\hline 32 & Cedrol & - & 0.22 & 0.12 & $\mathrm{C}_{15} \mathrm{H}_{26} \mathrm{O}$ & sesquiterpene alcohol. \\
\hline 33 & gamma-Sitosterol & - & 0.89 & 0.56 & $\mathrm{C}_{29} \mathrm{H}_{50} \mathrm{O}$ & $\begin{array}{l}\text { Steroid, antidiabetic drug } \\
\text { (Tripathi et al., 2013). }\end{array}$ \\
\hline 34 & Paromomycin & - & 0.12 & 0.22 & $\begin{array}{l}\mathrm{C}_{23} \mathrm{H}_{45} \mathrm{~N}_{5} \mathrm{O}_{1} \\
4\end{array}$ & $\begin{array}{l}\text { Treatment of diarrhea and } \\
\text { protozoa infections (Olajuyigbe } \\
\text { et al., 2018). }\end{array}$ \\
\hline 35 & Heptanal & 0.20 & - & - & $\mathrm{C}_{7} \mathrm{H}_{14} \mathrm{O}$ & $\begin{array}{l}\text { aldehyde antibacterial activity } \\
\text { (Lamba, 2007). }\end{array}$ \\
\hline 36 & Ionone & 0.33 & - & - & $\mathrm{C}_{13} \mathrm{H}_{20} \mathrm{O}$ & $\begin{array}{l}\text { Sesquiterpenoids, antimicrobial } \\
\text { agents (Sharma et al., 2012). }\end{array}$ \\
\hline 37 & Chloroxylenol & 0.16 & - & - & $\mathrm{C}_{8} \mathrm{H}_{9} \mathrm{OCl}$ & $\begin{array}{l}\text { phenols with antiseptic activity, } \\
\text { It is used in the manufacture of } \\
\text { disinfectants and sterilizers } \\
\text { (McDonnell, 2009). }\end{array}$ \\
\hline 38 & 1-Heptadecene & 0.22 & - & - & $\mathrm{C}_{17} \mathrm{H}_{34}$ & $\begin{array}{l}\text { unsaturated aliphatic } \\
\text { hydrocarbons. }\end{array}$ \\
\hline 39 & Undecanal & 0.25 & - & - & $\mathrm{C}_{10} \mathrm{H}_{21} \mathrm{CHO}$ & fatty aldehyde lipid molecule. \\
\hline 40 & $\begin{array}{l}\text { 1H-Indene, 2,3- } \\
\text { dihydro-1,1,2,3,3- } \\
\text { pentamethyl }\end{array}$ & 9.63 & - & - & $\mathrm{C}_{14} \mathrm{H}_{20}$ & No report was found. \\
\hline 41 & Epiglobulol & 0.97 & - & - & $\mathrm{C}_{15} \mathrm{H}_{26} \mathrm{O}$ & Alcohol. \\
\hline 42 & tau-Cadinol & 1.64 & - & - & $\mathrm{C}_{15} \mathrm{H}_{26} \mathrm{O}$ & No report was found. \\
\hline 43 & alpha-Cadinol & 0.38 & - & - & $\mathrm{C}_{15} \mathrm{H}_{26} \mathrm{O}$ & $\begin{array}{l}\text { Antifungal activity (Cheng et al., } \\
\text { 2012). }\end{array}$ \\
\hline 44 & Phytol, acetate & 0.37 & - & - & $\mathrm{C}_{22} \mathrm{H}_{42} \mathrm{O}_{2}$ & $\begin{array}{l}\text { Food additive, antimicrobial, } \\
\text { anti-inflammatory, anticancer } \\
\text { and antidiuretic properties } \\
\text { (Sermakkani and } \\
\text { Thangapandian, 2012). }\end{array}$ \\
\hline 45 & $\begin{array}{l}\text { 1S,2S,5R-1,4,4- } \\
\text { Trimethyltricyclo } \\
{[6.3 .1 .0(2,5)}\end{array}$ & 1.26 & - & - & $\mathrm{C}_{15} \mathrm{H}_{24}$ & No report was found. \\
\hline 46 & $\begin{array}{l}\text { beta-iso-Methyl } \\
\text { ionone }\end{array}$ & 0.39 & - & - & $\mathrm{C}_{14} \mathrm{H}_{22} \mathrm{O}$ & No report was found. \\
\hline 47 & Longipinane, (E)- & 0.41 & - & - & $\mathrm{C}_{15} \mathrm{H}_{24}$ & No report was found. \\
\hline 48 & $\begin{array}{l}\text { (-)-Isolongifolol, } \\
\text { methyl ether }\end{array}$ & 0.70 & - & - & $\mathrm{C}_{16} \mathrm{H}_{28} \mathrm{O}$ & Ether. \\
\hline 49 & Taraxasterol & 0.07 & - & - & $\mathrm{C}_{30} \mathrm{H}_{50} \mathrm{O}$ & $\begin{array}{l}\text { Anti-tumor and } \\
\text { chemopreventive activity } \\
\text { (Ovesná and Horvathova, 2004). }\end{array}$ \\
\hline 50 & $\begin{array}{l}\text { S-Methyl } \\
\text { methanethiosulphona } \\
\text { te }\end{array}$ & 0.07 & - & - & $\begin{array}{l}\mathrm{CH}_{3} \mathrm{SO}_{2} \mathrm{SCH} \\
3\end{array}$ & $\begin{array}{l}\text { Ester, Antimutagenic agent and } \\
\text { antimicrobial activity (Joller et } \\
\text { al., 2020; Miguel et al., 2016). }\end{array}$ \\
\hline 51 & 1-Heptatriacotanol & 0.23 & - & - & $\mathrm{C}_{37} \mathrm{H}_{76} \mathrm{O}$ & Fatty alcohol. \\
\hline 52 & 2-Vinylfuran & & 0.83 & & $\mathrm{C}_{6} \mathrm{H}_{6} \mathrm{O}$ & $\begin{array}{l}\text { Antimicrobial activity (Drobnica } \\
\text { and Sturdík, 1980). }\end{array}$ \\
\hline 53 & Salicyl hydrazide & - & 0.39 & - & $\mathrm{C}_{7} \mathrm{H}_{8} \mathrm{~N}_{2} \mathrm{O}_{2}$ & $\begin{array}{l}\text { Phenolic compounds, } \\
\text { antimicrobial activity, Anti- } \\
\text { inflammatory (Madan et al., }\end{array}$ \\
\hline
\end{tabular}




\begin{tabular}{|c|c|c|c|c|c|c|}
\hline & & & & & & 2014). \\
\hline 54 & $\begin{array}{l}\text { Isobutyl 4- } \\
\text { hydroxybenzoate }\end{array}$ & - & 8.91 & - & $\mathrm{C}_{11} \mathrm{H}_{14} \mathrm{O}_{3}$ & No report was found. \\
\hline 55 & $\begin{array}{l}\text { Methyl(ethenyl)bis(b } \\
\text { ut-3-en-1-ynyl) } \\
\text { silane }\end{array}$ & - & 1.62 & - & $\mathrm{C}_{7} \mathrm{H}_{16} \mathrm{Si}$ & No report was found. \\
\hline 56 & beta Carotene & - & 0.16 & - & $\mathrm{C}_{40} \mathrm{H}_{56}$ & $\begin{array}{l}\text { Carotenoids used as food, } \\
\text { nutrition, antioxidant, disease } \\
\text { control, and antimicrobial agents } \\
\text { (Kirti et al., 2014). }\end{array}$ \\
\hline 57 & $\begin{array}{l}\text { 17-Norkaur-15-ene, } \\
\text { 13-methyl-, } \\
\text { (8.beta.,13.b }\end{array}$ & - & 1.05 & - & $\mathrm{C}_{20} \mathrm{H}_{32}$ & No report was found. \\
\hline 58 & $\begin{array}{l}\text { 3-Hydroxy-2-(2- } \\
\text { methylcyclohex-1- } \\
\text { enyl) propan- }\end{array}$ & - & 1.48 & - & $\mathrm{C}_{10} \mathrm{H}_{16} \mathrm{O}_{2}$ & No report was found. \\
\hline 59 & $\begin{array}{l}\text { Cyclopropanebutanoi } \\
\text { c acid, } 2-[[2-[[2-[(2- \\
\text { pen }\end{array}$ & - & 1.20 & - & $\mathrm{C}_{11} \mathrm{H}_{22} \mathrm{~N}_{2} \mathrm{O}_{4}$ & No report was found. \\
\hline 60 & $\begin{array}{l}\text { Cholan-24-oic acid, } \\
\text { methyl ester, } \\
\text { (5.beta.)- }\end{array}$ & - & 1.56 & - & $\mathrm{C}_{25} \mathrm{H}_{40} \mathrm{O}_{3}$ & No report was found. \\
\hline 61 & $\begin{array}{l}\text { Lup-20(29)-en-3-ol, } \\
\text { acetate, (3.beta.)- }\end{array}$ & - & 1.12 & - & $\mathrm{C}_{32} \mathrm{H}_{52} \mathrm{O}_{2}$ & No report was found. \\
\hline 62 & $\begin{array}{l}\text { geranyl-.alpha.- } \\
\text { terpinene }\end{array}$ & - & 0.80 & - & $\mathrm{C}_{20} \mathrm{H}_{32}$ & Terpinene. \\
\hline 63 & $\begin{array}{l}\text { Tungsten, } \\
\text { tricarbonyl-(2,5- } \\
\text { norbornadiene) }\end{array}$ & - & - & 1.32 & $\mathrm{C}_{14} \mathrm{H}_{16}$ & No report was found. \\
\hline 64 & 1,2-Cyclopentanedione & - & - & 1.21 & $\mathrm{C}_{7} \mathrm{H}_{10} \mathrm{O}_{2}$ & $\begin{array}{l}\text { Prevents gastrointestinal } \\
\text { tumor growth (Neeraj et al., } \\
\text { 2019). }\end{array}$ \\
\hline 65 & $\begin{array}{l}\text { 2-Cyclopenten-1- } \\
\text { one, 2-hydroxy-3- } \\
\text { methyl- }\end{array}$ & - & - & 0.34 & $\mathrm{C}_{6} \mathrm{H}_{8} \mathrm{O}_{2}$ & No report was found. \\
\hline 66 & $\begin{array}{l}\text { 1,2,3-Propanetriol, } 1- \\
\text { acetate }\end{array}$ & - & - & 1.23 & $\mathrm{C}_{5} \mathrm{H}_{10} \mathrm{O}_{4}$ & No report was found. \\
\hline 67 & $\begin{array}{l}\text { Acetoacetic acid, 3- } \\
\text { thio-, benzyl ester }\end{array}$ & - & - & 0.16 & $\mathrm{C}_{11} \mathrm{H}_{12} \mathrm{O}_{2}$ & No report was found. \\
\hline 68 & $\begin{array}{l}\text { trans-Z-.alpha.- } \\
\text { Bisabolene epoxide }\end{array}$ & - & - & 1.11 & $\mathrm{C}_{15} \mathrm{H}_{24} \mathrm{O}$ & No report was found. \\
\hline 69 & $\begin{array}{l}\text { 2-Hydroxyoctanoic } \\
\text { acid }\end{array}$ & - & - & 0.62 & $\mathrm{C}_{8} \mathrm{H}_{16} \mathrm{O}_{3}$ & No report was found. \\
\hline 70 & 1-Tetradecene & - & - & 0.67 & $\mathrm{C}_{14} \mathrm{H}_{28}$ & $\begin{array}{l}\text { Antimicrobial activity (Naragani } \\
\text { et al., 2016). }\end{array}$ \\
\hline 71 & $\begin{array}{l}\text { Benzoic acid, 4- } \\
\text { methoxy- }\end{array}$ & - & - & 0.69 & $\mathrm{C}_{8} \mathrm{H}_{8} \mathrm{O}_{3}$ & No report was found. \\
\hline 72 & Chlorozotocin & - & - & 0.20 & $\begin{array}{l}\mathrm{C}_{9} \mathrm{H}_{16} \mathrm{ClN}_{3} \mathrm{O} \\
7\end{array}$ & No report was found. \\
\hline 73 & $\begin{array}{l}\text { 2-Isopropyl-5- } \\
\text { methyl-6-oxabicyclo } \\
{[3.1 .0] \text { hex }}\end{array}$ & - & - & 1.51 & $\mathrm{C}_{10} \mathrm{H}_{16} \mathrm{O}_{2}$ & No report was found. \\
\hline 74 & Quinic acid & - & - & 2.96 & $\mathrm{C}_{7} \mathrm{H}_{12} \mathrm{O}_{6}$ & Anti-viral activity (Özçelik et \\
\hline
\end{tabular}




\begin{tabular}{|c|c|c|c|c|c|c|}
\hline & & & & & & al., 2011). \\
\hline 75 & $\begin{array}{l}\text { 3-Methylindene-2- } \\
\text { carboxylic acid }\end{array}$ & - & - & 1.11 & $\mathrm{C}_{11} \mathrm{H}_{10} \mathrm{O}_{2}$ & No report was found. \\
\hline 76 & $\begin{array}{l}\text { O, O-Dibutyl S-(2- } \\
\text { acetamidoethylmerca } \\
\text { pto) p }\end{array}$ & - & - & 1.32 & $\mathrm{C}_{12} \mathrm{H}_{22} \mathrm{O}_{4}$ & No report was found. \\
\hline 77 & $\begin{array}{l}\text { 3-Deoxy-d-mannonic } \\
\text { acid }\end{array}$ & - & - & 1.21 & $\mathrm{C}_{6} \mathrm{H}_{12} \mathrm{O}_{6}$ & No report was found. \\
\hline 78 & $\begin{array}{l}\text { Cyclooctane-1,4-diol, } \\
\text { cis }\end{array}$ & - & - & 0.44 & $\mathrm{C}_{8} \mathrm{H}_{16} \mathrm{O}_{2}$ & No report was found. \\
\hline 79 & $\begin{array}{l}\text { cis, cis, cis-7,10,13- } \\
\text { Hexadecatrienal }\end{array}$ & - & - & 0.58 & $\mathrm{C}_{16} \mathrm{H}_{26} \mathrm{O}$ & Unsaturated fatty aldehyde. \\
\hline 80 & $\begin{array}{l}\text { 10-Iodo-7-oxa-2- } \\
\text { thia-tricyclo } \\
{[4.3 \cdot 1.0(3,8)] \mathrm{de}}\end{array}$ & - & - & 1.08 & $\mathrm{C}_{8} \mathrm{H}_{11} \mathrm{IOS}$ & No report was found. \\
\hline 81 & $\begin{array}{l}\text { Bicyclo [6.1.0] } \\
\text { nonane, 9-(1- } \\
\text { methylethylidene }\end{array}$ & - & - & 3.66 & $\mathrm{C}_{12} \mathrm{H}_{20}$ & No report was found. \\
\hline 82 & Inositol & - & - & 0.15 & $\mathrm{C}_{6} \mathrm{H}_{12} \mathrm{O}_{6}$ & $\begin{array}{l}\text { Essential nutrient, Cancer } \\
\text { chemoprevention agent, } \\
\text { treatment for Polycystic Ovary } \\
\text { Syndrome and insulin } \\
\text { sensitizing agent (Carlomagno } \\
\text { and Unfer, 2011). }\end{array}$ \\
\hline 83 & Xylose & - & - & 0.15 & $\mathrm{C}_{5} \mathrm{H}_{10} \mathrm{O}_{5}$ & $\begin{array}{l}\text { Pentose sugar (Huntley and } \\
\text { Patience, 2018). }\end{array}$ \\
\hline 84 & Scyllo-Inositol & - & - & 1.18 & $\mathrm{C}_{6} \mathrm{H}_{12} \mathrm{O}_{6}$ & $\begin{array}{l}\text { treatment of Alzheimer's disease } \\
\text { (Ma et al., 2012). }\end{array}$ \\
\hline 85 & $\begin{array}{l}\text { 2,4-Pentadien-1-ol, } \\
\text { 3-pentyl-, (2Z)- }\end{array}$ & - & - & 0.94 & $\mathrm{C}_{10} \mathrm{H}_{18} \mathrm{O}$ & No report was found. \\
\hline 86 & $\begin{array}{l}\text { Widdrol } \\
\text { hydroxyether }\end{array}$ & - & - & 0.23 & $\mathrm{C}_{15} \mathrm{H}_{26} \mathrm{O}_{2}$ & No report was found. \\
\hline 87 & Stigmasterol & - & - & 0.21 & $\mathrm{C}_{29} \mathrm{H}_{48} \mathrm{O}$ & $\begin{array}{l}\text { Steroid, antioxidant, } \\
\text { antimicrobial, anticancer, } \\
\text { antiarthritic, antiasthma, } \\
\text { anti-inflammatory, diuretic } \\
\text { (Tyagi and Agarwal, 2017; } \\
\text { Kumar et al., 2014). }\end{array}$ \\
\hline 88 & beta.-Amyrin & - & - & 0.43 & $\mathrm{C}_{30} \mathrm{H}_{50} \mathrm{O}$ & $\begin{array}{l}\text { Triterpenes, anti-inflammatory } \\
\text { (Okoye et al., 2014). }\end{array}$ \\
\hline 89 & $\begin{array}{l}\text { 5,5'-Dihydroxy-3,3'- } \\
\text { dimethyl-2,2'- } \\
\text { binaphthal }\end{array}$ & - & - & 1.31 & $\mathrm{C}_{17} \mathrm{H}_{14} \mathrm{O}_{6}$ & No report was found. \\
\hline 90 & Lanosterol & - & - & 0.22 & $\mathrm{C}_{30} \mathrm{H}_{50} \mathrm{O}$ & $\begin{array}{l}\text { Sterol, essential components of } \\
\text { eukaryotic cells (Wei et al., } \\
\text { 2016). }\end{array}$ \\
\hline 91 & Betulin & - & - & 0.58 & $\mathrm{C}_{30} \mathrm{H}_{50} \mathrm{O}_{2}$ & $\begin{array}{l}\text { Anti-Viral and anti- tumour } \\
\text { (Tolstikov et al., 2005). }\end{array}$ \\
\hline 92 & $\begin{array}{l}\text { alpha-Tocopheryl } \\
\text { acetate }\end{array}$ & - & - & 0.23 & $\mathrm{C}_{31} \mathrm{H}_{52} \mathrm{O}_{3}$ & $\begin{array}{l}\text { Antimicrobial activity (Bidossi } \\
\text { et al., 2017). }\end{array}$ \\
\hline 93 & Geldanamycin & - & - & 0.33 & $\mathrm{C}_{29} \mathrm{H}_{40} \mathrm{~N}_{2} \mathrm{O}_{9}$ & Chemotherapeutic agents \\
\hline
\end{tabular}




\begin{tabular}{|c|c|c|c|c|c|c|}
\hline & & & & & & (da Rocha et al., 2001). \\
\hline 94 & Dihydrosteviobiside & - & - & 0.26 & $\mathrm{C} 32 \mathrm{H} 52 \mathrm{O} 13$ & No report was found. \\
\hline 95 & Bronopol & - & - & 0.10 & $\mathrm{C}_{3} \mathrm{H}_{6} \mathrm{BrNO}_{4}$ & $\begin{array}{l}\text { Antimicrobial activity (Birkbeck } \\
\text { et al., 2006; Treasurer et al., } \\
\text { 2005). }\end{array}$ \\
\hline \multicolumn{2}{|c|}{$\begin{array}{c}\text { Total compounds for each } \\
\text { solvent }\end{array}$} & 47 & 43 & 52 & & \\
\hline
\end{tabular}

